J. Asiat. Soc. Bangladesh, Sci. 46(2): 155-162, December 2020

\title{
EXTRACTION AND PROXIMATE STUDY OF SANSEVIERIA TRIFASCIATA L. AS FIBRE SOURCE FOR TEXTILE AND OTHER USES
}

\author{
A.B.M. ABDULLAH ${ }^{1}$, MARUF ABONY ${ }^{2}$, M.T. ISLAM ${ }^{1}$, M.S. HASAN ${ }^{1}$, \\ M.A.K. OYON ${ }^{1}$ AND MD. BOKHTIAR RAHMAN ${ }^{3} *$ \\ ${ }^{I}$ Departments of Textile Engineering, Primeasia University, Banani, Dhaka, Bangladesh. \\ ${ }^{2}$ Departments of Microbiology, Primeasia University, Banani, Dhaka, Bangladesh. \\ ${ }^{3}$ Department of Biochemistry and Molecular Biology, Hajee Mohammad Danesh \\ Science and Technology University, Dinajpur, Bangladesh.
}

\begin{abstract}
Natural fibres are getting importance for their sustainable development in their uses in mitigation of climate change and ecological balance. A fibre extraction retting method is formulated and proximate chemical composition and various physical properties such as tensile strength, elongation, diameter along with fibre, cellulose, lignin and ash content were determined. This preliminary observation indicates its potential to be used as a source of fibre for textile and non-textile uses such as woven, nonwoven, composite, blanded and a good source of $\alpha$-cellulose, microcrystalline cellulose, nano-cellulose and lignin-based products.
\end{abstract}

Key word: Ecology, Retting, Sansevieria trifasciata L., Microcrystal cellulose and lignin.

\section{Introduction}

The horizon of diversified uses of natural fibres is increasing for sustainable development strategy. Ecofriendly, biodegradability, recyclable and reusable properties of cellulosic and lignocellulosic fibres such as cotton, jute, kenaf, ramie, etc. are gaining focus and the marketing of their products are increasing (Kanimozhi 2011a, Kant and Alagh 2013, Wolela 2019). Cellulosic and lingo cellulosic fibres are bio-polymer and obtain from a large variety of plants and crops (Wolela 2019).

Recently, various studies are undertaken to find fibres from different non-conventional and indigenous sources such as banana, bamboo, water-hyacinth, etc. Sansevieria trifasciata L. is a long leafy plant (Fig.1). Sansevieria is a genus of 70 species with great variation within the genus such as from succulent Sansevieria pinguicula to the leafy tropical plant, such as Sansevieria trifasciata L. (Wolela 2019). They are native to India,

*Corresponding authors: <abm.abdullah45@yahoo.com and bokhtiarbdj@gmail.com>. 
Indonesia and Africa (Kanimozhi 2011a, Wolela 2019). It is an evergreen and perennial plant. Its leaves grow vertically from the Basal rosette. Its leaves are a stiff, swordshaped, band with yellow on either slightly band center. But matured leaf is deep green with light gray-green cross bending usually $70-90 \mathrm{cms}$ long, 5-6 cms wide. Indigenously, it is called in different names as "snake plant, mother in laws tongue", Saint George's sword, bowstring hemp, in our locality it is called "Baghachokor". It is a thicked leaves fibres laminated with waxy membrane type of smooth surface (Abral and Kenedy 2015, Kanimozhi 2011b, Kumar et al. 2011, Wolela 2019).

Presently, this plant is urbanized as a decorative garden plant for their air purification characteristics property and converting $\mathrm{CO}_{2}$ into $\mathrm{O}_{2}$ at night (Kant and Alagh 2013). Some parts of the plant are medicinally important in the traditional system of medicine in India and other countries as fodder, edible and mosquito repellant (Rose et al. 2017).

In the present study, matured Sansevieria trifasciata L. leaves were collected from Phokir-Bari garden, Kapasia, Gazipur. The primary objective of this study is to identify fibre extraction method and proximate studies such as fibre content, chemical composition and other physical properties such as strength, diameter, colour, elongation, moisture content, etc.

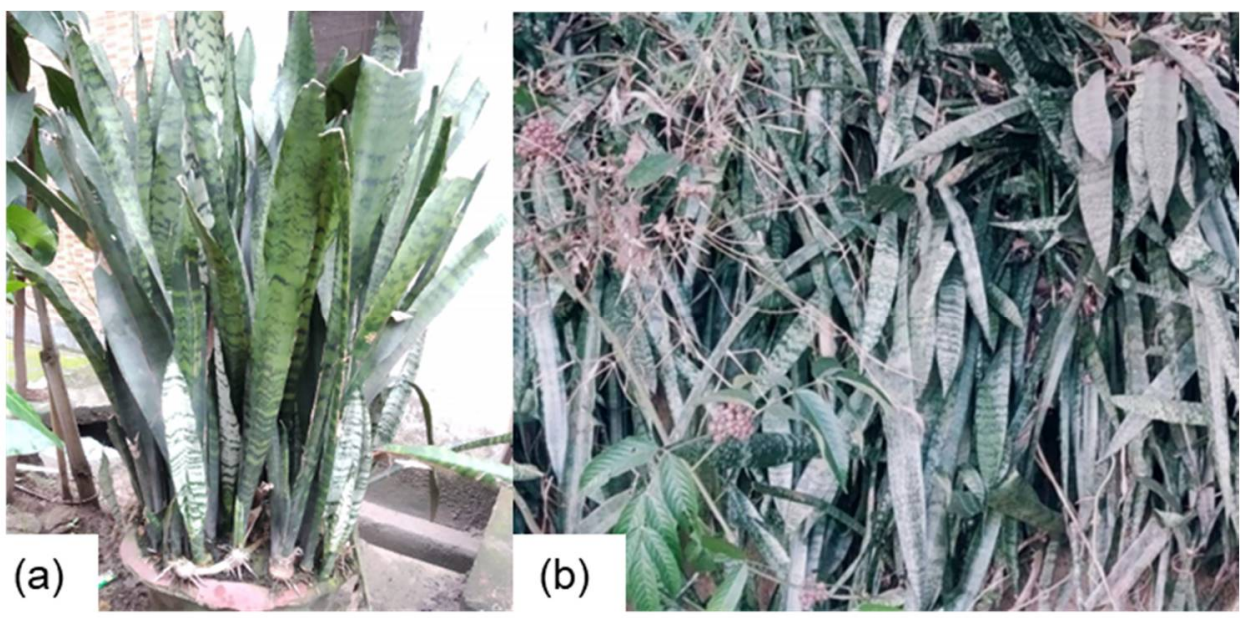

Fig. 1. Sansevieria trifasciata plants (a) in pot culture and (b) in bush.

Extraction can be made manually by hand, water retting, dew retting, chemical retting decortication, etc. (Murthy and Karthikeyan 2015). Retting is a complex biochemical process where bacteria and enzymes play a complex role in separating fibre from the leaf. 
In this study, a composite Chemi-Biochemi-Mechanical method has tried to accelerate the retting process with minimal water and time of retting.

\section{Materials and Methods}

In this study, a Chemi-Biochemi-Mechanical retting method was formulated for accelerated fibre extraction from Sansevieria trifasciata L. collected from the local bush. In this process, clean, gray-white, shining and bright fibres were obtained in 48-72 hrs whereas in mechanical, chemical and water retting extraction of similar fibre were obtain having longer time ( 3 weeks) involving higher temperature $\left(70^{\circ} \mathrm{C}\right)$ and a greater amount of chemicals (5\% NaOH) (Kant and Alagh 2013, Wolela 2019).

Green leaves were cut down into 2-3 inches pieces after gently hammering it. A number of experiments were undertaken with the variation of retting time, $\mathrm{pH}$, liquor ratio, the concentration of alkali, urea, molasses and observed fibre yield by occasional examination/test and color/ordor of retting water. All experiments were carried out at room temperature $\left(25-29^{\circ} \mathrm{C}\right)$ and washed with tap water in the dyeing laboratory of Primeasia University and the following recipe was determined:

Sansevieria trifasciata L. leaves- 50 gms, NaOH- $1-2 \%$ on the weight of material (O.W.M), Urea- 2-3\% (O.W.M.), Molasses- $1 \%$ (O.W.M.), pH- 9-11, L.R.- 1 : 20, Temperature- $25-29{ }^{\circ} \mathrm{C}$, Times- 2-3 days, Stirring- occasionally, Solution colour- green and Odor- pungent and eye sensitive.

After retting, fibre was thoroughly washed with tap water until it was freed from colour and waxy materials, and finaly, it was washed with distilled water. Hydro-extracted fibres were dried at room temperature in an open atmosphere.

Hammered leaves (500 gms) were retted in a big bucket by following the modified method of Abdullah et al. (1987) and fibres were obtained and washed and dried as before and obtained results are shown in Table 1.

Similarly, chemical composition and physical properties were determined with standard laboratory methods and conditions at dyeing and microbiology laboratories, Primeasia University (PAU), Banani, Dhaka. The following results were obtained and shown in Tables 2 and 3.

\section{Results and Discussion}

Properties of fibre extracted with this method and compared with the results from other sources are shown in Table 4. 
Table 1. Crude fibre properties.

\begin{tabular}{lll}
\hline Content & Amount & $\%$ \\
\hline Fibre yield & 16 to $17 \mathrm{gm}$ & 3 \\
Waxy material & $1-5 \mathrm{gm}$ & 1.06 \\
Residue & - & \\
Liquid color & Green solution & \\
Fibre color & Gray white (slight yellowish) & \\
Fibre shape & Smooth, distinct, less branching & \\
Crimpiness & Lack of crims & \\
Brightness & Silky and shiny & \\
Diameter & Cylindrical and Uniform & \\
\hline
\end{tabular}

Table 2. Chemical composition.

\begin{tabular}{lc}
\hline Component & $\%$ \\
\hline Cellulose content & $70-75$ \\
Lignin Content & $16-18$ \\
Ash content & $2-3$ \\
Fatty materials & $10-12$ \\
\hline
\end{tabular}

Table 3. Physical properties.

\begin{tabular}{ll}
\hline Fibre properties & \\
\hline Tensile strength & $5.97-6.0$ gm/denin \\
Diameter & $40-50$ micron \\
Elongation at break in \% & $3.12-3.80$ \\
Breaking strength in gm & $110-112$ \\
$\begin{array}{l}\text { Moisture content in \% } \\
\text { Color change after exposure to sunlight in } \\
\text { normal days light } 10 \text { am to } 3 \text { pm (100 hours } \\
\text { exposure) }\end{array}$ & $12-13$ \\
\hline
\end{tabular}


Table 4. Comparison of extracted fibre properties with that of other sources.

\begin{tabular}{|c|c|c|c|}
\hline \multirow[t]{2}{*}{ Fibre properties } & \multirow[t]{2}{*}{ Observed } & \multicolumn{2}{|r|}{ Other sources } \\
\hline & & Value & Reference \\
\hline Average number of fibre/ single leaf & $680-720$ & 772 & (Wolela 2019) \\
\hline Fibre yield in $\%$ & $2-3$ & $3-4$ & (Wolela 2019) \\
\hline Fibre length in $\mathrm{cm}$ & $60-85$ & 90 & (Wolela 2019) \\
\hline Diameter in micron & $45-48$ & 50.76 & (Kant and Alagh 2013) \\
\hline Breaking strength in gms & $110-112$ & 114.99 & (Kant and Alagh 2013) \\
\hline Elongation at the break in $\%$ & $2.9-3.1$ & 3.27 & (Kant and Alagh 2013) \\
\hline Moisture content in $\%$ & $12-13$ & $13.1 / 13.9$ & (Wolela 2019) \\
\hline Tensile strength gm/diner & $12-14$ & 15.54 & (Wolela 2019) \\
\hline Colour & Grey white & Grey white & (Wolela 2019) \\
\hline $\begin{array}{l}\text { Colour change in sunlight after } \\
\text { exposer in normal sun light for } 10 \\
\text { am to } 3 \mathrm{pm} \\
\text { (100 hours) }\end{array}$ & $\begin{array}{l}\text { Colour } \\
\text { change to } \\
\text { yellow to } \\
\text { brown }\end{array}$ & - & - \\
\hline Cellulose content in $\%$ & $70-75$ & - & - \\
\hline Lignin content in $\%$ & $16-18$ & - & - \\
\hline Ash content in \% & $2-3$ & - & - \\
\hline Fatty materials in $\%$ & $8-10$ & - & - \\
\hline STPLR (fibre content) in $\%$ & $2-3$ & - & - \\
\hline
\end{tabular}

Sansevieria trifasciata leaf fibre (STLF) is a lingo cellulosic fibre like a jute, kenaf, and ramie though they are bast fibre, the retting method, which is adopted here, is a slight modification of bast fibre and coconut fibre retting (Abdullah et al. 1987). As depictured above, comparative physical properties indicated that the retting recipe and method is a positive improvement of traditional and chemical extraction methods practice in fibre extraction methods from STLF. This is an experimental laboratory study, further and critical studies and pilot-plant experimentation will be needed to find and postulate optimal commercial adaptation methods.

Preliminary experimentation indicates that this fibre can be scoured, bleached and can be dyed in commercial dyes (Fig. 2) through a slight modification of existing facilities (Abdullah et al. 2019). Sustainable and ecofriendly development needs renewable biomass and energy. In addition to traditional natural fibre, new indigenous sources of fibres are highly needed to protect the environment and climate change induced disaster. 
STLF is natural wild fibres and its origin is in India, Indonesia and Africa. They grow anywhere in full sunlight, shade and even in the dark but thrive in a moist, fertile land with high organic content with minimum or no agronomic care (Kant and Alagh 2013).

Presently, as a decorative garden plant and air purification, roof-agriculture has better potentiality (Kant and Alagh 2013). Moreover, leaf fibre plants have a higher degree of fibre yielding capacities. A comprehensive socio-economic study is highly needed for taking any commercial ventures.

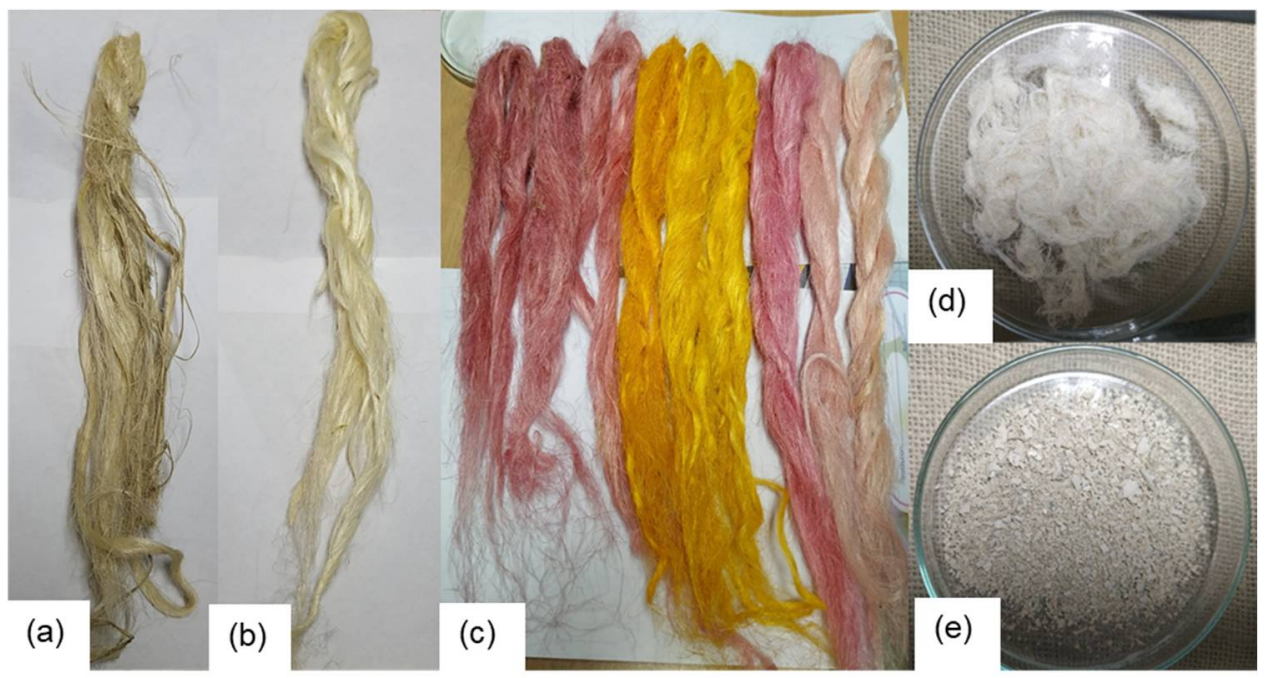

Fig. 2. Preliminary observation of STLF and products. (a) Untreated fibres, (b) bleached fibres, (c) dyed fibres, (d) cellulose and (e) crude microcrystalline cellulose.

Though it is leafy fibres still like other bast fibres the color change in sunlight occurred due to lignin.

From the observation, in the above-compared Table 4, it is showed that the fibre content here is $2-3 \%$ whereas, in jute, flax and banana fibre content are 2, 27 and 2.6\%, respectively (Whewell 1948). In comparison, it is better than jute but lower in flax. On the other hand, banana fibre is coarser and shorter fibre length with less cellulose content.

Total cellulose content indicates it has a potentiality of $\alpha$-cellulose, microcrystalline cellulose and other cellulose derivatives and pulp and paper. Other properties, like the number of fibres single leaf, breaking strength, diameter, and moisture content, are its positive side. But, poor crispiness indicates its spainablity will be different from present 
coton/jute spinning, but there is enough potential to be used in handicraft as a string, cord, decorative materials in boutique production and decoration of Jamdani and Katan products (Abdullah 2019). Murthy and Karthikeyan (2015) reported that its roots have the potential for the production of various nano products along with some medicinal values. The synthesis of nanoparticles has received much attention for its wide range of applications. The aqueous root and bark extracts of STLF act both as a reducing and capping agent (Rose et al. 2017). Due to the presence of flavonoids, it can be used as an antibacterial and antioxidant agent as well as an inhibitor of xanthine oxidase enzyme, which is the main culprit of hyperuricemia (Yumna et al. 2018).

Sansevieria trifasciata $L$. is a wild leafy fibres plant. It is a source of strong white fibre. They are commonly used as rope, fishing lines/net, cordage, bowstring and clothing materials. From the results of the above study and information, it can be inferred that this fibre and other parts of this plant have the potential for wide-scale used and diversified product development for the use as a raw material in different industries such as textile and garments, pulp and paper, pharmaceuticals and cosmetics along with various decorative furnishing industries. Renewable and ecologically natural fibres are in great demand for a sustainable and pollution-free planet. Sansevieria trifasciata $L$. is leafy and perennial fibre. Climatic and agro-ecological conditions reflect the possibility of widescale production in our non-agricultural and bushy barrel land along with newly practices urbanized roof-agriculture and environmental mitigation.

\section{References}

Abral, H. and E. Kenedy. 2015. Thermal degradation and tensile strength of Sansevieria trifasciatapolypropylene composites. Paper presented at the IOP Conference Series: Materials Science and Engineering, 87. doi:10.1088/1757-899X/87/1/012011

Abdullah, A.B.M. 2019. Personal Communication with Bibi Russel, renowned fashion designer. Mid-september.

Abdullah, A.B.M., M.T. Islam, M.S. Hasan and M. A. Oyon. 2019. A study of dyeability properties of newly extracted fibres STET of local source. Accepted for publication to Journal of Primeasia Univ. 2(1): 34-44.

Abdullah, A.B.M., M.K. Kabir, B. Rahman, F. Uddin, N.N. Khan and H.U. Ahmed. 1987. Production of jute/coir blended yarn from low grade jute and coir fibres. Bangladesh J. Jute and Fibre Res. 12(1\&2): 27-30.

Kanimozhi, M. 2011a. Investigating the physical characteristics of Sansevieria trifasciata fibre. Intl. J. Sci. Res. Pub. 1(1): 1-4.

Kanimozhi, M. 2011b. Extraction, fabrication and evaluation of Sansevieria trifascicata fiber. Ind. J. Appl. Res. 1: 97-98. 
Kant, R. and P. Alagh. 2013. Extraction of fiber from Sansevieria trifasciata plant and its properties. Intl. J. Sci. Res, 4(7): 2547-2549.

Kumar, M.A., G.R. Reddy, G.H. Reddy, N.S. Reddy, K.H. Reddy and Y. Reddy. 2011. Mechanical properties of randomly oriented short Sansevieria trifasciata fibre/epoxy composites. $J$. Metallurgy and Materials Sci. 53: 85-95.

Murthy, V.N. and N. Karthikeyan. 2015. Development of Sansevieria trifasciata-carbon fiber reinforced polymer hybrid nanocomposites. ILVPA 50: 179-187.

Rose, A.L., F.J. Priya and S. Vidhya. 2017. Comparative study on the synergistic action of differentially synthesized copper nanoparticles with Escherichia coli and Staphylococcus aureus. Intl. Res. J. Pharm. 8(11): 85-90.

Whewell, C. 1948. Matthews' Textile fibers: their physical, microscopical and chemical properties. Nature, 161(4094): 581.

Wolela, A.D. 2019. Extraction and characterization of natural cellulose fibers from Sanseveria trifasciata plant. TTEFT 5(2): 630-634.

Yumna, M., R. Arbianti, T.S. Utami, H. Hermansyah and S. Ningsih. 2018. Flavonoid isolation and identification of mother-in-law's tongue leaves (Sansevieria trifasciata) and the inhibitory activities to xanthine oxidase enzyme. E3S Web of Conferences, 67: 1-6. https://doi. org/ $10.1051 / \mathrm{e} 3$ sconf/20186703011

(Revised copy received on 08.9.2020) 